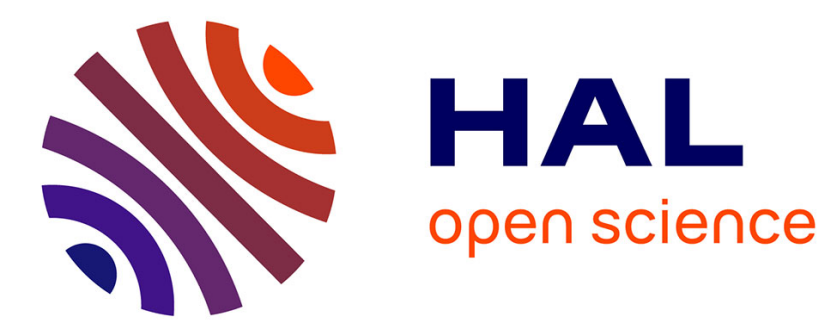

\title{
Peri-operative complications in children with Apert syndrome: A review of 509 anaesthetics.
}

\author{
Sarah Barnett, Claire Moloney, Robert Bingham
}

\section{To cite this version:}

Sarah Barnett, Claire Moloney, Robert Bingham. Peri-operative complications in children with Apert syndrome: A review of 509 anaesthetics.. Pediatric Anesthesia, 2010, 21 (1), pp.72. 10.1111/j.14609592.2010.03457.x . hal-00599906

\section{HAL Id: hal-00599906 https://hal.science/hal-00599906}

Submitted on 11 Jun 2011

HAL is a multi-disciplinary open access archive for the deposit and dissemination of scientific research documents, whether they are published or not. The documents may come from teaching and research institutions in France or abroad, or from public or private research centers.
L'archive ouverte pluridisciplinaire HAL, est destinée au dépôt et à la diffusion de documents scientifiques de niveau recherche, publiés ou non, émanant des établissements d'enseignement et de recherche français ou étrangers, des laboratoires publics ou privés. 


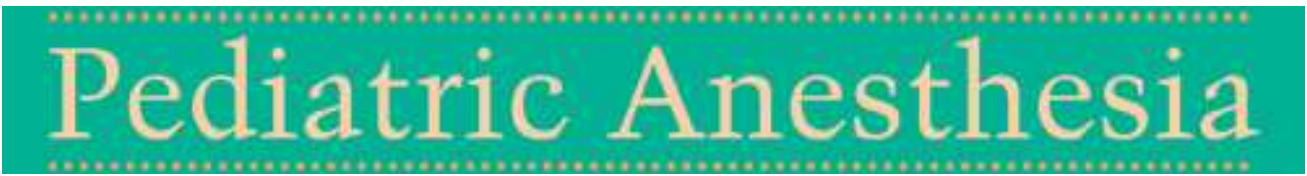

\section{Peri-operative complications in children with Apert syndrome: A review of 509 anaesthetics.}

\begin{tabular}{|c|c|}
\hline Journal: & Pediatric Anesthesia \\
\hline Manuscript ID: & PAN-2010-0426.R1 \\
\hline Wiley - Manuscript type: & Original Paper \\
\hline $\begin{array}{r}\text { Date Submitted by the } \\
\text { Author: }\end{array}$ & 21-Oct-2010 \\
\hline Complete List of Authors: & $\begin{array}{l}\text { Barnett, Sarah; Great Ormond Street Hospital, Anaesthetics } \\
\text { Moloney, Claire; Great Ormond Street Hospital, Anaesthetics } \\
\text { Bingham, Robert; Great Ormond Street Hospital, Anaesthetics }\end{array}$ \\
\hline Key Words: & $\begin{array}{l}\text { Apert syndrome, peri-operative complications, mid-face hypoplasia, } \\
\text { obstructive sleep apnoea, airway management }\end{array}$ \\
\hline
\end{tabular}

\section{SCHOLARONE Manuscripts}


1

2

3

4

5

6

7

8

9

10

11

12

13

14

15

16

17

18

19

20

21

Peri-operative complications in children with Apert syndrome: A review of 509 anaesthetics.

Dr Sarah Barnett MBBS FRCA Specialist Registrar,

Dr Claire Moloney MBBS FRCA Specialist Registrar,

Dr Robert Bingham MBBS FRCA Consultant,

Great Ormond Street Hospital, Great Ormond Street, London, WC1N 3JH

Email for correspondence:sarahfbarnett@googlemail.com

Address for correspondence: Dr Sarah Barnett, 48, Trinity Church Square, London, SE1 4HT 


\begin{abstract}
:
Objectives: To perform a retrospective, anaesthesia case note review in children with Apert

Syndrome.
\end{abstract}

Aim: To identify peri-operative complications in this group of patients.

Background: Apert syndrome is a rare autosomal dominant disorder characterized by craniosynostosis, craniofacial anomalies, and severe symmetrical syndactyly (cutaneous and bony fusion) of the hands and feet. Children with this syndrome require general anaesthetics for a number of different operations and procedures. Our institution has records of 71 children with Apert syndrome. Analysis of their general anaesthetic records was undertaken and the incidence of perioperative complications was investigated.

Methods: A retrospective case note review was performed on 61 children with Apert syndrome over a 14 year period. There were a total of 509 general anaesthetics administered to these children during this period of time.

Results: There were a total of 31 peri-operative respiratory complications occurring in 21 patients (6.1\% of the total cases). 23 of these complications were supraglottic airway obstruction $(4.5 \%$ of total cases).

Conclusions: We found there to be a low incidence of major peri-operative major complications in this group of patients. Nevertheless, a significant proportion of these children have obstructive sleep apnoea and may develop supraglottic airway obstruction on induction and emergence from anaesthesia due to the associated mid-face anatomical abnormalities.

Keywords: Apert syndrome; peri-operative complications; mid-face hypoplasia; obstructive sleep apnoea, airway management 


\section{Introduction}

Apert syndrome is a rare disorder which generally occurs sporadically, although an autosomal dominant inheritance has been described[1]. It is evident at birth, and accounts for $4.5 \%$ of all cases of craniosynostosis (premature fusion of one or more cranial sutures). Further craniofacial abnormalities include hypertelorism, midface hypoplasia and choanal stenosis. Neurological and intracranial anomalies can include ventriculomegaly, hydrocephalus[2] and developmental delay[3]. The other dominant clinical feature is symmetrical syndactyly of the fingers[4] and feet (cutaneous and bony fusion) generally tending to affect the upper limb more severely than the lower $\operatorname{limb}[5]$. There have also been reports of associated congenital cardiac and renal defects. There is fusion of the cervical spine in $68 \%$ of cases of Apert syndrome, mainly at C5-C6, distinguishing it from Crouzons syndrome where the fusion is usually at the C2-C3 level[6].

These features have clinical relevance to anaesthetists as some degree of upper airway obstruction due to reduced nasopharyngeal volume and choanal patency is certain. Obstructive sleep apnoea is present in almost 50\%[7] and cor pulmonale may result[8]. There have also been descriptions of complete or partial cartilage sleeve abnormalities of the trachea, which has been postulated to cause lower airway compromise[9].

Children with this syndrome require general anaesthetics for a number of different operations and procedures. It has been suggested that they have a much higher incidence of peri-operative respiratory complications, particularly bronchospasm, than other children[10]. There is very little published data looking specifically at peri-operative outcomes in children with Apert syndrome. Reviews and reports tend to group them together with other craniofacial syndromes[11-13], so specific complications may be masked. Our institution has records of 71 children with Apert syndrome diagnosed clinically and genetically. Analysis of their general anaesthetic records was undertaken and the incidence of peri-operative complications was investigated. 


\section{Methods}

Following ethical and audit committee advice a retrospective case note review was performed on 71 children with Apert syndrome at Great Ormond Street Hospital. Eight case notes were untraceable during the period of time due to filing and tracking errors and therefore omitted from the series and a further 2 sets of case notes had no records of anaesthesia. The anaesthetic charts from the case notes of the remaining 61 children were analysed for the 14 year period from 1995 until 2009.

Details of patient demographics and the procedures undertaken were collated. The patient's preoperative respiratory status was recorded, specifically looking for a sleep study diagnosis of obstructive sleep apnoea, a history of asthma or wheeze, tracheostomies, and previous respiratory admissions. Intra-operative airway management and complications were documented, and the postoperative period was evaluated.

\section{Results}

There were a total of 509 general anaesthetics administered to 61 children ( 38 males and 23 females) during this 14 year period of time. Their ages ranged from 1 day to 15 years old, and they were classified as ASA II ( $n=77)$ and ASA III ( $n=431)$, with operation duration ranging from 10 minutes to over 4 hours.

The most frequent reason for a general anaesthetic was an orthopaedic procedure (Table 1.). Within the 224 operations undertaken 115 of these were for a change of dressing. There were 46 major craniofacial operations, the majority of which were posterior vault expansions, frontal remodelling and biparietal distractions (Table 2.). The remaining minor craniofacial procedures included adjustments and removals of 'RED (Rigid Extraction Device) frames'. 


\section{1}

Thirty six children had a sleep study diagnosis of obstructive sleep apnoea pre-operatively. Although we were unable to clarify the exact age of the children when they were diagnosed, their ages when presenting for surgery ranged from 6 weeks to 14 years. Two of these children, aged 11 and 12, were receiving home CPAP. Eight out of the nine adenotonsillectomy patients in this series were having the procedure in an attempt to ameliorate OSA. Only 5 of the patients had a history of asthma or being 'wheezy' in the past. Three of these children were taking regular inhalers for the condition. Six children had a tracheostomy, at some point during their lives. The indication for four of these children was temporary insertion because of craniofacial surgery. One child had a tracheostomy at the age of $\mathbf{2}$ weeks to assist prolonged ventilatory requirements. One child had a definitive tracheostomy for severe obstructive sleep apnoea. Fifteen children had known choanal atresia, and one child had congenital subglottic stenosis. Eight of the children had been admitted to hospital with respiratory symptoms since birth, and on sixteen occasions the patients had experienced a recent upper respiratory tract infection prior to their anaesthetic (Table 3.).

Atropine was prescribed before 216 anaesthetics and sedation was given before 44 procedures. The majority of times, no premedication was given $(n=293)$. A majority of the anaesthetics were initiated with a gas induction (251 vs. 58 intravenous). Maintenance of anaesthesia was with volatile agents in all but one of the anaesthetics where total intravenous anaesthesia (TIVA) was used. The patients received positive pressure ventilation for 225 of the anaesthetics, and in the remaining 284 cases the child breathed spontaneously throughout the procedure.

The airway was managed in a variety of ways - face mask $(n=68, S V=66, P P V=2)$, laryngeal mask $(n=206, S V=206)$, tracheal tube $(n=199, S V=2, P P V=197)$ and tracheostomy $(n=36, S V=10, P P V=26)$ The children were easy to intubate in the majority of cases with a Cormack and Lehane grade I $(n=181)$, grade II $(n=15)$ and grade III $(n=3)$. There were no children with a grade IV view. There were 2 cases where the laryngeal mask did not provide a good seal; one was managed with tracheal intubation and the other with a face mask. 
Nasal prongs were in situ prior to 19 anaesthetics in 4 children. Another 6 children had a nasal prong placed at the end of their operations.

In 98 of the 199 occasions, an age appropriate tracheal tube size was used according to the formula: tracheal tube size (internal diameter in millimetres) $=($ age/4 $)+4$. In 68 instances a larger tube size was required, and a smaller tracheal tube was placed in 28 cases. There were 5 anaesthetics where the tube size was not documented (Table 4.).

Peripheral access was documented in 457 of the anaesthetics. On 52 occasions there was no intravenous access. There were 45 arterial lines and 30 central venous catheters placed.

The majority of orthopaedic operations were upper limb procedures and brachial plexus blocks $(n=80)$ were commonly performed. Limited abduction of the upper arm and 'winging' of the scapula in Apert syndrome makes axillary brachial plexus block difficult to perform and ultrasound guidance is helpful. The remaining regional blocks were caudal epidurals $(n=3)$, and an ankle block $(n=1)$.

There were a total of 31 peri-operative respiratory complications occurring in 21 patients $16.1 \%$ of the total cases). 23 of these complications were supra-glottic airway obstruction (4.5\% of total cases), which were easily resolved with simple airway manoeuvres, adjuncts or positive end expiratory pressure (PEEP) (Table 5.). There was only one documented incidence of wheeze, which followed fentanyl and erythromycin administration and was clinically felt to be allergy related although no treatment was required. The child was 3 years old, having syndactyly release surgery and was breathing spontaneously through a laryngeal mask. The child had a recent URTI but subsequent anaesthetic charts documented this event as an antibiotic allergy. Other problems were: desaturation due to secretions down the tracheal tube, resolved with suctioning (x1); Laryngospasm requiring re-intubation (x1); Self resolving stridor in recovery (x1); Post-operative upper airway clot after micro-laryngo-bronchoscopy $(\mathrm{x} 1)$; Coughing on induction $(\mathrm{x} 1)$; Obstruction of nasal prong on postoperative ward leading to respiratory arrest and PICU admission (x1); Desaturation and 
drowsiness in recovery after monoblock distraction $(x 1)$, which was successfully treated with naloxone and furosemide.

Five children had a past medical history of asthma/wheeze and 3 of these were taking regular inhalers for the condition; the patient who experienced wheeze under anaesthesia was not one of this cohort. Thirty-six patients had a formal sleep study diagnosis of obstructive sleep apnoea but only 9 of these had documented peri-operative supraglottic airway obstruction. Only 3 children with a recent URTI had documented peri-operative respiratory complications; 1 (described previously) associated with wheeze and allergy; 1 with tracheal tube secretions and the other with supraglottic airway obstruction.

There was one patient with a major bleed following a bipartition distraction, who required unexpected admission to the PICU for ongoing management. Two children vomited, one on induction and the other on emergence, but neither resulted in aspiration.

The majority of patients returned to the ward/ HDU environment after their operations $(n=494)$ with only 15 admissions to the PICU/NICU post-operatively.

\section{Discussion}

Although a retrospective case note review may well under-report complications, we are confident that major problems requiring treatment will have been captured. Overall, we found there to be a low incidence of major peri-operative respiratory complications in this group of patients and in contrast to a previous publication[10], we found the incidence of bronchospasm to be extremely low at $0.2 \%$ and there were no cancellations of surgery due to respiratory complications.

The lower airway abnormalities described in the literature did not cause excessive problems in our cohort, tracheal tube size was either age appropriate or greater in $83.4 \%$ of the group and only one 
child had a documented congenital sub-glottic stenosis[9]. In one child, there was desaturation related to partial obstruction of the tracheal tube by secretions and although this was easily resolved, we note that this complication has been reported previously[14]. Tracheobronchial secretions may also cause lower airway obstruction and mimic bronchospasm, which may account for some of the cases previously described.

Our results showed that our group of patients were far more likely to experience supra-glottic rather than infra-glottic obstruction. It may be that this was under-reported in our data, as minor degrees of supra-glottic obstruction may not have caused the anaesthetist or patient substantial problems and may have seemed unworthy of reporting. Simple airway manoeuvres and adjuncts usually rectified any upper airway obstruction documented. The majority of upper airway obstructions occurred on induction of anaesthesia. There were only four incidences of postoperative obstructions. A common supposition would be to assume the incidence of postoperative problems occurs more frequently with longer intubations and prolonged surgery. Our results do not support this statement. The majority of the supraglottic obstructions occurred when the child was scheduled to have 'shared airway' surgery such as Ear, Nose and Throat (ENT) and dental procedures. Perioperative airway complications were encountered infrequently in the major craniofacial operations. Just over half of the incidents of supraglottic obstruction arose in children under the age of $\mathbf{2}$ years, which is not unexpected. We find it re-assuring to have collected data which demonstrates that if supra-glottic airway obstruction does occur, laryngoscopy and intubation is generally easy. It should be noted however, that although surgical mid-face advancement improves the cosmetic appearance, it results in a marked deterioration of laryngoscopic view and this may cause unexpected difficulties[15, 16].

Our data demonstrates that patients with Apert syndrome may require many anaesthetics of relatively short duration. A large proportion of the anaesthetics were of less than 30 minutes and 
this explains the large proportion of cases where the patient was breathing spontaneously either with a face-mask or laryngeal mask airway.

In 52 of the anaesthetic charts there was no peripheral vascular access. This was a deliberate policy intended to preserve valuable vascular access sites during hand dressing changes. An intraosseous device was immediately available for all these cases but was never required.

In our cohort of patients the peri-operative problems occurred in 21 children (34\%), which is a similar incidence to Elwood et al. who reported respiratory complications in 33\% of patients[10]. Very few of the complications were serious and none resulted in cancellation of the procedure so it is important that a population of patients are not incorrectly labelled as 'high risk'. Nevertheless a significant proportion of these children have obstructive sleep apnoea and may develop supraglottic airway obstruction on induction and emergence from anaesthesia due to the mid-face anatomical abnormalities associated with this syndrome and the anaesthetist must be prepared to deal with this.

The authors have no financial or other interests to declare.

\section{Acknowledgements}

We would like to thank the craniofacial nurse specialists Andrea White and Kathy Truscott for their help obtaining the list of patients. 


\section{References}

[1] Mantilla-Capacho JM, Arnaud L, Diaz-Rodriguez M, Barros-Nunez P. Apert syndrome with preaxial polydactyly showing the typical mutation Ser252Trp in the FGFR2 gene. Genet Couns. 2005;16(4):403-6.

[2] Quintero-Rivera F, Robson CD, Reiss RE, Levine D, Benson CB, Mulliken JB, et al. Intracranial anomalies detected by imaging studies in 30 patients with Apert syndrome. Am J Med Genet A. 2006 Jun 15;140(12):1337-8.

[3] Cohen MM, Jr., Kreiborg S. The central nervous system in the Apert syndrome. Am J Med Genet. 1990 Jan;35(1):36-45.

[4] Wilkie AO, Slaney SF, Oldridge M, Poole MD, Ashworth GJ, Hockley AD, et al. Apert syndrome results from localized mutations of FGFR2 and is allelic with Crouzon syndrome. Nat Genet. 1995 Feb;9(2):165-72.

[5] Cohen MM, Jr., Kreiborg S. Hands and feet in the Apert syndrome. Am J Med Genet. 1995 May 22;57(1):82-96.

[6] Kreiborg S, Barr M, Jr., Cohen MM, Jr. Cervical spine in the Apert syndrome. Am J Med Genet. 1992 Jul 1;43(4):704-8.

[7] Bannink N, Nout E, Wolvius EB, Hoeve HL, Joosten KF, Mathijssen IM. Obstructive sleep apnea in children with syndromic craniosynostosis: long-term respiratory outcome of midface advancement. Int J Oral Maxillofac Surg. 2010 Feb;39(2):115-21.

[8] Kaplan LC. Clinical assessment and multispecialty management of Apert syndrome. Clinics in plastic surgery. 1991 Apr;18(2):217-25.

[9] Cohen MM, Jr., Kreiborg S. Upper and lower airway compromise in the Apert syndrome. Am J Med Genet. 1992 Sep 1;44(1):90-3.

[10] Elwood T, Sarathy PV, Geiduschek JM, Ulma GA, Karl HW. Respiratory complications during anaesthesia in Apert syndrome. Paediatr Anaesth. 2001 Nov;11(6):701-3.

[11] Mallory S, Yap LH, Jones BM, Bingham R. Anaesthetic management in facial bipartition surgery: the experience of one centre. Anaesthesia. 2004 Jan;59(1):44-51.

[12] Sculerati N, Gottlieb MD, Zimbler MS, Chibbaro PD, McCarthy JG. Airway management in children with major craniofacial anomalies. Laryngoscope. 1998 Dec;108(12):1806-12.

[13] Uppington J, Goat VA. Anaesthesia for major craniofacial surgery: a report of 23 cases in children under four years of age. Ann R Coll Surg Engl. 1987 Jul;69(4):175-8.

[14] Basar H, Buyukkocak U, Kaymak C, Akpinar S, Sert O, Vargel I. An intraoperative unexpected respiratory problem in a patient with Apert syndrome. Minerva Anestesiol. 2007 Nov;73(11):603-6.

[15] Morris GP, Cooper MG. Difficult tracheal intubation following midface distraction surgery. Paediatr Anaesth. 2000;10(1):99-102. 
1

2

3

4

5

6

7

8

9

10

11

12

13

14

15

16

17

18

19

20

21

22

23

24

25

26

27

28

29

30

31

32

33

34

35

36

37

38

39

40

41

42

43

44

45

46

47

48

49

50

51

52

53

54

55

56

57

58

59

60

[16] Roche J, Frawley G, Heggie A. Difficult tracheal intubation induced by maxillary distraction devices in craniosynostosis syndromes. Paediatr Anaesth. 2002 Mar;12(3):227-34. 
Table 1. Type of surgery.

\begin{tabular}{lc}
\hline Type & Number of Anaesthetics \\
\hline Orthopaedics & 224 \\
ENT & 79 \\
Neurosurgery & 62 \\
Radiology & 51 \\
Craniofacial & 46 \\
Dental & 18 \\
Plastics/Cleft surgery & 10 \\
General & 10 \\
Eyes & 7 \\
Urology & 1 \\
Cardiac & 1 \\
&
\end{tabular}

Table 2. Major craniofacial reconstructions.

\begin{tabular}{ll}
\hline Procedure & Number of cases \\
\hline Bipartition distraction & 7 \\
Monoblock distraction & 5 \\
Frontal remodelling & 8 \\
Cranial vault expansion & 5 \\
Posterior vault expansion & 16
\end{tabular}


Table 3. Patient demographics.

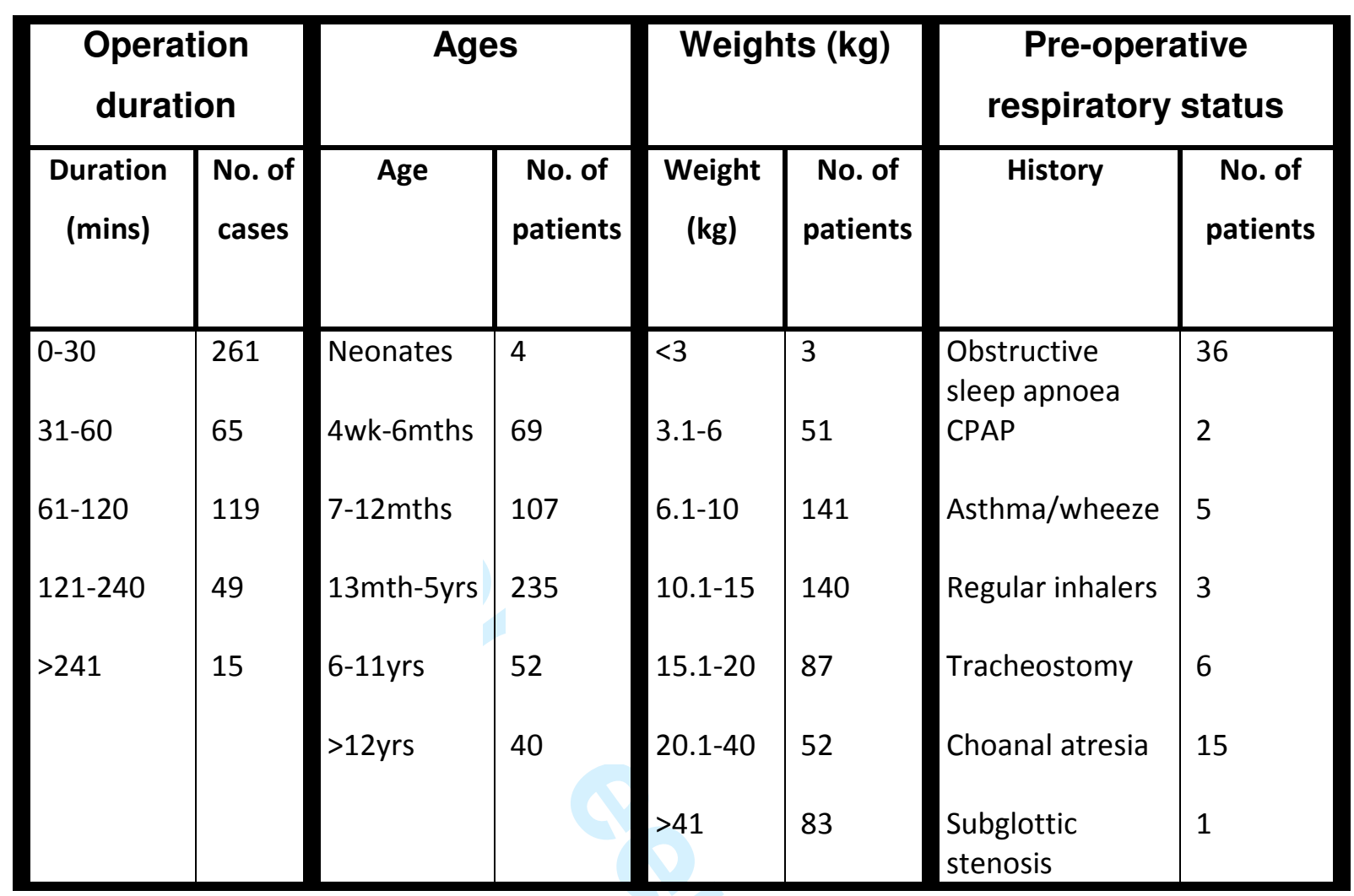

Table 4. Age appropriate tracheal tube sizes (based on the formula: Tracheal tube internal diameter $(\mathrm{mm})=\mathrm{age} / 4+4)$.

\begin{tabular}{lll}
\hline Tube size & Numbers & Percentage \\
\hline Age appropriate & $98 / 199$ & $49.2 \%$ \\
Larger size & $68 / 199$ & $34.2 \%$ \\
Smaller size & $28 / 199$ & $14.1 \%$ \\
Unclear & $5 / 199$ & $2.5 \%$ \\
\hline
\end{tabular}


Table 5. Details of patients who experienced supraglottic airway obstruction.

\begin{tabular}{|c|c|c|c|c|c|c|c|}
\hline Patient & Age & $\begin{array}{l}\text { Known } \\
\text { preoperative } \\
\text { Upper } \\
\text { Airway } \\
\text { obstruction? }\end{array}$ & Surgery & $\begin{array}{l}\text { Duration } \\
\text { of } \\
\text { surgery }\end{array}$ & $\begin{array}{l}\text { Timing of } \\
\text { obstruction }\end{array}$ & $\begin{array}{l}\text { Manipulation } \\
\text { of airway to } \\
\text { overcome } \\
\text { obstruction }\end{array}$ & $\begin{array}{l}\text { Definitive } \\
\text { airway for } \\
\text { proceedure }\end{array}$ \\
\hline 1. & 3 yrs & Yes - OSA & $\begin{array}{l}\text { Tonsillectomy } \\
\text { and } \\
\text { Adenoidectomy }\end{array}$ & 60 mins & Induction & $\begin{array}{l}\text { Oropharyngeal } \\
\text { airway }\end{array}$ & Tracheal tube \\
\hline 2. & $\begin{array}{l}19 \\
\text { mths }\end{array}$ & No & $\begin{array}{l}\text { Fronto-orbital } \\
\text { remodelling }\end{array}$ & $6 \mathrm{hrs}$ & Induction & $\begin{array}{l}\text { Oropharyngeal } \\
\text { airway }\end{array}$ & Tracheal tube \\
\hline 3a. & $\begin{array}{l}8 \\
\text { mths }\end{array}$ & Yes - OSA & $\begin{array}{l}\text { Change of } \\
\text { dressing }\end{array}$ & 20 mins & Induction & $\begin{array}{l}\text { Oropharyngeal } \\
\text { airway and } \\
\text { PEEP }\end{array}$ & $\begin{array}{l}\text { Face mask and } \\
\text { oropharyngeal } \\
\text { airway }\end{array}$ \\
\hline $3 b$. & $\begin{array}{l}9 \\
\text { mths }\end{array}$ & Yes - OSA & $\begin{array}{l}\text { Change of } \\
\text { dressing }\end{array}$ & 20 mins & Induction & $\begin{array}{l}\text { Oropharyngeal } \\
\text { airway }\end{array}$ & $\begin{array}{l}\text { Face mask and } \\
\text { oropharyngeal } \\
\text { airway }\end{array}$ \\
\hline 3c. & $\begin{array}{l}9 \\
\text { mths }\end{array}$ & Yes - OSA & $\begin{array}{l}\text { Tonsillectomy } \\
\text { and } \\
\text { Adenoidectomy }\end{array}$ & 30 mins & Induction & $\begin{array}{l}\text { Oropharyngeal } \\
\text { airway }\end{array}$ & Tracheal tube \\
\hline $4 a$. & $12 \mathrm{yrs}$ & $\begin{array}{l}\text { Yes-OSA. } \\
\text { Nocturnal } \\
\text { CPAP }\end{array}$ & $\begin{array}{l}\text { Dental } \\
\text { extractions }\end{array}$ & $\begin{array}{l}2 \text { hrs } 45 \\
\text { mins }\end{array}$ & Induction & $\begin{array}{l}\text { Jaw support } \\
\text { and suction }\end{array}$ & Tracheal tube \\
\hline $4 b$. & 9 yrs & Yes - OSA & $\begin{array}{l}\text { Tonsillectomy } \\
\text { and } \\
\text { Adenoidectomy, } \\
\text { EUA ears }\end{array}$ & $\begin{array}{l}1 \mathrm{hr} 15 \\
\operatorname{mins}\end{array}$ & Induction & Jaw support & Tracheal tube \\
\hline 5. & $14 \mathrm{yrs}$ & No & $\begin{array}{l}\text { Correction of } \\
\text { fixed flexion } \\
\text { deformity of } \\
\text { hand }\end{array}$ & 40 mins & Induction & PEEP & Tracheal tube \\
\hline 6. & $\begin{array}{l}4 \\
\text { mths }\end{array}$ & $\begin{array}{l}\text { Yes- } \\
\text { OSA/choanal } \\
\text { atresia }\end{array}$ & $\begin{array}{l}\text { Adenoidectomy, } \\
\text { EUA postnasal } \\
\text { space }\end{array}$ & 60 mins & Induction & Jaw support & Tracheal tube \\
\hline 7. & $\begin{array}{l}5 \\
\text { mths }\end{array}$ & $\begin{array}{l}\text { Yes - } \\
\text { OSA/choanal } \\
\text { atresia }\end{array}$ & $\begin{array}{l}\text { Frontal } \\
\text { remodelling }\end{array}$ & $4 \mathrm{hrs}$ & Induction & LMA & Tracheal tube \\
\hline 8. & $5 \mathrm{yrs}$ & Yes - OSA & Adenoidectomy & 40 mins & Induction & Jaw thrust & Tracheal tube \\
\hline 9. & $14 \mathrm{yrs}$ & Yes - OSA & $\begin{array}{l}\text { Syndactyly } \\
\text { repair }\end{array}$ & $1 \mathrm{hr}$ & Emergence & $\begin{array}{l}\text { Oropharyngeal } \\
\text { airway until } \\
\text { awake }\end{array}$ & Tracheal tube \\
\hline 10a. & $\begin{array}{l}9 \\
\text { mths }\end{array}$ & $\begin{array}{l}\text { Yes- } \\
\text { OSA/choanal } \\
\text { atresia }\end{array}$ & $\begin{array}{l}\text { Nasal prong and } \\
\text { dilation }\end{array}$ & 20 mins & Induction & $\begin{array}{l}\text { Oropharyngeal } \\
\text { airway and } \\
\text { nasal prong }\end{array}$ & LMA \\
\hline $10 \mathrm{~b}$. & $\begin{array}{l}2 \mathrm{yrs} \\
10 \\
\mathrm{mths}\end{array}$ & Yes - OSA & CT Head & 10 mins & Induction & $\begin{array}{l}\text { Oropharyngeal } \\
\text { airway }\end{array}$ & LMA \\
\hline 11a. & $\begin{array}{l}4 \\
\text { mths }\end{array}$ & No & $\begin{array}{l}\text { Cleft palate } \\
\text { repair }\end{array}$ & $\begin{array}{l}1 \mathrm{hr} 30 \\
\text { mins }\end{array}$ & Induction & $\begin{array}{l}\text { Oropharyngeal } \\
\text { airway }\end{array}$ & Tracheal tube \\
\hline 11b. & $\begin{array}{l}9 \\
\text { mths }\end{array}$ & No & $\begin{array}{l}\text { Syndactyly } \\
\text { repair }\end{array}$ & $\begin{array}{l}3 \mathrm{hrs} 30 \\
\text { mins }\end{array}$ & Induction & $\begin{array}{l}\text { Oropharyngeal } \\
\text { airway }\end{array}$ & Tracheal tube \\
\hline 12. & 12 & No & Grommets & 10 mins & Induction & Oropharyngeal & LMA \\
\hline
\end{tabular}




\begin{tabular}{|c|c|c|c|c|c|c|c|}
\hline & mths & $\begin{array}{l}\text { (subsequently } \\
\text { diagnosed } \\
\text { OSA) }\end{array}$ & & & & $\begin{array}{l}\text { airway and } \\
\text { PEEP }\end{array}$ & \\
\hline 13. & $\begin{array}{l}6 \\
\text { weeks }\end{array}$ & Yes - OSA & $\begin{array}{l}\text { MLB and nasal } \\
\text { prong }\end{array}$ & 60 mins & Induction & Nasal prong & Nasal prong \\
\hline 14. & 14 yrs & Yes - OSA & $\begin{array}{l}\text { Cranial cyst } \\
\text { enucleation }\end{array}$ & $\begin{array}{l}1 \mathrm{hr} 30 \\
\text { mins }\end{array}$ & Emergence & Jaw thrust & Tracheal tube \\
\hline 15. & 4 yrs & No & $\begin{array}{l}\text { Division of } \\
\text { fingertips }\end{array}$ & 60 mins & Induction & $\begin{array}{l}\text { Jaw thrust and } \\
\text { PEEP }\end{array}$ & Tracheal tube \\
\hline $16 a$. & $\begin{array}{l}7 \\
\text { mths }\end{array}$ & No & $\begin{array}{l}\text { Cranial } \\
\text { remodelling }\end{array}$ & $2 \mathrm{hrs}$ & Emergence & $\begin{array}{l}\text { Oropharyngeal } \\
\text { airway }\end{array}$ & Tracheal tube \\
\hline $16 \mathrm{~b}$. & 4 yrs & No & $\begin{array}{l}\text { Change of } \\
\text { dressing }\end{array}$ & 10 mins & Induction & PEEP & Face mask \\
\hline $16 c$. & 9yrs & No & $\begin{array}{l}\text { Dental } \\
\text { extractions }\end{array}$ & 30 mins & Emergence & Chin lift & Tracheal tube \\
\hline
\end{tabular}




\section{Legends to tables:}

Table 1. Type of surgery.

Table 2. Major craniofacial reconstructions.

Table 3. Patient demographics.

Table 4. Age appropriate tracheal tube sizes (based on the formula: Tracheal tube internal diameter $(\mathrm{mm})=\mathrm{age} / 4+4)$

Table 5. Details of patients who experienced supraglottic airway obstruction. 


\section{Colour Work Agreement Form}

Form No: SN_Sub2000_P_CoW

If you have any problems or queries please contact the Production Editor for guidance (details can be found in the Instructions for Authors)

If you have submitted a manuscript that contains colour figures, it is the policy of the journal for authors to meet the full cost of colour reproduction. Blackwell Publishing require you to complete this form. Please fill in your contact details and then complete the table as instructed. Note: this form must be filled in for all manuscripts that have been submitted with colour work, even if you subsequently choose not to publish either in print or online in colour.

\section{We are unable to process your manuscript until we receive your instructions so please return this form as quickly as possible!}

Journal name:

$$
\text { PAEDiatric anaestitesia }
$$

Corresponding Author:

$$
\text { SARAH BARNETT }
$$

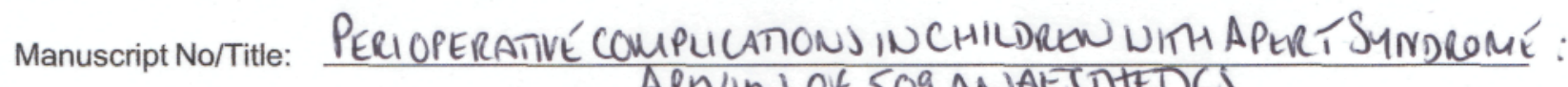
Your Name: SARAH BARNET

Address: 48 TRWITM CIURCH SQUARE, LONDON, SEI 4 HT

Fax: Tel: 07971633042

e-mail: Sarahfbarnettegooglemail com

\section{WHAT YOU NEED TO DO}

Please complete the table on page 2, placing an ' $X$ ' in the relevant column for each figure.

The costs are shown at the top of each column. Please calculate the total cost for each category at the foot of the table, and then add VAT if applicable (see below).

\section{All customers MUST quote their VAT numbers}

Customers in the UK: add VAT at $17.5 \%$.

\section{Customers elsewhere in the EU:}

- Customers registered for VAT: No VAT (please complete details below)

VAT registration number:

Name of organisation:

- Customers NOT registered for VAT: Add VAT at $17.5 \%$.

\section{Customers outside the EU: No VAT}

PAGE 1

\begin{tabular}{|l|l|l|l|l|}
\hline \multicolumn{5}{|c|}{$<<<$ For internal use ONLY $>>$} \\
\hline JPCMS No & Journal acronym & Volume & Issue & Print run \\
\hline & & & & \\
\hline
\end{tabular}


Please now complete this table (Remember: only one ' $X$ ' per figure).

\begin{tabular}{|c|c|c|c|}
\hline Figure Number & $\begin{array}{l}\text { Column } 1 \\
\text { Colour in print and online }{ }^{*}\end{array}$ & $\begin{array}{l}\text { Column } 2 \\
\text { Colour online ONLY }\end{array}$ & $\begin{array}{l}\text { Column } 3 \\
\text { Black \& white in print and online }\end{array}$ \\
\hline Costs & $\begin{array}{l}\text { 1st figure }=£ 150 \\
\text { Subsequent figures }=£ 50 \text { each }\end{array}$ & $£ 50$ each & Free \\
\hline 1 & & & $x$ \\
\hline 2 & & & $X$ \\
\hline 3 & & & $X$ \\
\hline 4 & & & $x$ \\
\hline 5 & & & $x$ \\
\hline 6 & & & $\lambda$ \\
\hline \multicolumn{4}{|l|}{7} \\
\hline \multicolumn{4}{|l|}{8} \\
\hline \multicolumn{4}{|l|}{9} \\
\hline \multicolumn{4}{|l|}{10} \\
\hline $\begin{array}{l}\text { Total number of } \\
\text { figures of each type }\end{array}$ & & & 6 \\
\hline
\end{tabular}

\begin{tabular}{|ll|ll|}
\hline \multicolumn{4}{|c|}{${ }^{*}$ Quick cost lookup table for colour figures in print and online: } \\
\hline No. of colour figs & Cost & No. of colour figs & Cost \\
\hline 1 & $£ 150$ & 6 & $£ 400$ \\
2 & $£ 200$ & 7 & $£ 450$ \\
3 & $£ 250$ & 8 & $£ 500$ \\
4 & $£ 300$ & 9 & $£ 550$ \\
5 & $£ 350$ & 10 & $£ 600$ \\
\hline
\end{tabular}

Column 1 total $£$

Column 2 total $£$

VAT (if applicable) $£$

Total: $£ 0$

\section{Payment by Credit Card (MasterCard/VISA/American Express)}

Blackwell Publishing accepts payment in three major currencies:

Pounds Sterling, United States Dollars and the Euro. Please indicate which currency you would like to pay in: Pounds Sterling (£) $\square$ / United States Dollars* (US\$) $\square /$ Euros* $^{*}(€) \square$ (tick one)

${ }^{*}$ Conversions from US $\$$ or $€$ will be made at our monthly rate.

Please debit my credit card number:

Verification ID Number:

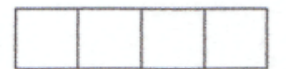

This can be found on your credit card (Visa/MasterCard have 3 numbers and Amex has 4)

Name on card

Expiry Date

With the sum of

NIL

Signature Surah SaMetA

Date $12 / 9 /, 0$

Note: payment by credit card can only be accepted if all sections are completed.

Please use BLOCK CAPITALS where possible.

\section{Payment by Purchase Order}

If you are asking your university or institution to pay we require purchase order details

l attach order number dated

Please now return all pages of your completed form as a scanned electronic file (preferred option), or by fax or post to the production editor for your journal. Contact details can be found in the instructions for authors. 